\title{
Micronutrient Deficiencies in Medical and Surgical Inpatients
}

\author{
Mette M Berger*(D), Olivier Pantet $\mathbb{D}^{\mathbb{D}}$, Antoine Schneider and Nawfel Ben-Hamouda \\ Service of Adult Intensive Care Medicine and Burns, Lausanne University Hospital (CHUV), BH 08.612, \\ Rue du Bugnon 46, 1011 Lausanne, Switzerland \\ * Correspondence: Mette.Berger@chuv.ch; Tel.: +41-21-3142095
}

Received: 30 May 2019; Accepted: 21 June 2019; Published: 28 June 2019

\begin{abstract}
Inpatients are threatened by global malnutrition, but also by specific micronutrient (i.e., trace element and vitamins) deficiencies that frequently are overseen in the differential diagnosis of major organ dysfunctions. Some of them are related to specific geographic risks (iodine, iron, selenium, zinc, vitamin A), while others are pathology related, and finally many are associated with specific feeding patterns, including low dose enteral feeding. Among the pathologies in which laboratory blood investigations should include a micronutrient outwork, anemia is in the front line, followed by obesity with bariatric surgery, chronic liver disease, kidney disease, inflammatory bowel disease, cardiomyopathies and heart failure. The micronutrients at the highest risk are iron, zinc, thiamine, vitamin B12 and vitamin C. Admission to hospital has been linked with an additional risk of malnutrition-feeding below $1500 \mathrm{kcal} /$ day was frequent and has been associated with a structural additional risk of insufficient micronutrient intake to cover basal needs. Although not evidence based, systematic administration of liberal thiamine doses upon admission, and daily complementation of inpatients' food and enteral feeding solutions with multi-micronutrient tablets might be considered.
\end{abstract}

Keywords: iron; copper; selenium; zinc; thiamine; vitamin B12; obesity; inflammation; enteral nutrition

\section{Introduction}

Malnutrition includes a wide spectrum of conditions [1] that may affect energy, substrates and micronutrients (i.e., trace elements and vitamins) to variable degrees. Deficiency is defined as a lack, or shortage of a specific micronutrient that is essential for the proper growth and metabolism of a human: 11 trace elements and 13 vitamins qualify as essential in humans [2,3].

Disease related malnutrition has shown to be frequent upon admission [4]. The proportion of patients that have been admitted to hospital in a poor nutritional status varies between nearly zero in trauma and up to $50 \%$ in oncologic pathologies [5,6], and has an important impact on costs [6]. Malnutrition affects all ages from pediatric [7] to geriatric admissions [8]. Elderly subjects constituted an important, increasing part of our population with specific physiopathologic characteristics [9]. In developing countries, socio-economic factors will generate specific deficiencies [10], which will also be present in migrant populations [11]. Further, some pathologies threaten more, particularly the micronutrient status. Finally, the geographic place of living in the world, including some western countries and the local soil characteristics, will have their own impact $[12,13]$. Iodine and iron deficiencies are the most well-known. The below text will review some of these undermining deficiencies.

The definition of deficiency requires knowing the specific needs of diseased patients-this information is generally not available. Micronutrient requirements have been determined for the healthy population with age specificities [3]. They are called dietary reference intakes (DRI), a concept that has replaced the recommended daily allowance (RDA). There is minimal data that exists about the needs during disease. Therefore, the present review, which is based on searches in PubMed and the 
Cochrane library, is focused on conditions in adults that have been best documented, such as elderly patients, and some selected conditions. The issue of refeeding syndrome in hospitalized patients is be given particular attention.

\section{Undermining Micronutrients Deficiencies}

The causes of deficiency can globally be divided into three: Low availability, reduction of intakes, and malabsorption. Some geographic soil and nutrition specificities have threatened the entire populations' micronutrient status. This knowledge is not new [2], and the below text provides a brief summary of their impact on acute diseases.

Micronutrient deficiencies have been called the hidden hunger [14], as they are determining and aggravating factors for one's health status and quality of life. The close relation between fetal malnutrition and the development of chronic non-communicable diseases later in life has been repeatedly confirmed [10,15]. Vitamin A (in developing countries), iodine, and iron deficiencies (worldwide) are the most important in terms of global public health [16]. The below deficiencies have affected patients before their hospital admission and should be integrated in the differential diagnosis of the acute condition.

\subsection{Iodine}

Deficiencies early in life impairs cognition and growth. Iodine status is also a key determinant of thyroid disorders in adults. Iodine deficiency disorders have affected 740 million people. A severe deficiency causes goiter and hypothyroidism because, despite an increase in thyroid activity to maximize iodine uptake and recycling, iodine concentrations are insufficient to enable synthesis of thyroid hormones [17].

\subsection{Iron}

Deficiencies are a public health problem worldwide [18]. In the year 2000, it was estimated that iron deficiency anemia affected two billion people, mostly women and children. Anemia concerns roughly a third of the world's population [19], but anemia represents the end stage of an iron deficiency [20] which is largely prevalent in all categories of society [21]. The diagnosis of this deficiency is complex in acute and chronic diseases presenting an inflammatory response that modulates blood iron concentrations [20,22]. Its efficient treatment has often been prevented by beliefs such as the risk of iron administration causing additional oxidative stress or favoring infection. These concerns have not been confirmed [23]. The exploration of the iron status (deficiency $<7.1 \mu \mathrm{g} / \mathrm{L}$ or $12.5 \mathrm{mmol} / \mathrm{L}$ ) included determining the presence of inflammation reflected by C-reactive protein (CRP) $>10 \mathrm{mg} / \mathrm{L}$ [24]. In addition to hemoglobin, and erythrocyte morphology (microcytosis, hypochromia), the following have been required: Serum ferritin $(<30 \mathrm{ng} / \mathrm{L})$, transferrin saturation $(<15 \%)$, total iron-binding capacity $(>13.1 \mu \mathrm{mol} / \mathrm{L}$ ), soluble transferrin receptor (increased $>28.1 \mathrm{nmol} / \mathrm{L}$ ) [20], and hepcidin (ranges men 0.6-23.3 nmol/L, women 0.4-19.7 nmol/L) [25].

With the availability of hepcidin as a marker of deficiency, the diagnosis should become easier $[20,22,25]$. Hepcidin is a hormone synthesized in the liver, secreted into the blood that systemically controls the rate of iron absorption as well as its mobilization from stores [26]. The synthesis of hepcidin is up-regulated by inflammatory cytokines (particularly interleukin-6), irrespective of the total level of iron in the body. This relationship most likely accounts for the development of anemia of chronic disease $[27,28]$ (please see Section 3.7 for specificities in kidney diseases).

\subsection{Selenium}

Deficiencies have been an issue in Europe and in other parts of the world as the main source of human exposure is diet, which is related to the soil content [29]. Scientists have claimed that changes in climate and the organic carbon content of soil will lead to overall decreased soil Se concentrations, particularly in agricultural areas [30]. Europe and some parts of Australasia are particularly affected, 
while North America is spared by elevated soil content. Borderline Se status reduced endogenous antioxidant defenses via the reduction of the activity of the glutathione peroxidase (GPX) family of enzymes [31], which contributed to poor outcomes facing critical illness, and particularly sepsis [32]. In major trauma, the intravenous administration of selenium in combination with other micronutrients at 5 times DRI doses (see Table 1) resulted in normalization of plasma GPX3 activity and shortened hospital stays [33]. Nevertheless, the high dose single selenium trials (1000 $\mu \mathrm{g} / \mathrm{iv} / \mathrm{day})$ in septic shock have been negative [34]. Therefore this strategy should not be considered, and has been advised against in the Surviving Sepsis Campaign 2017 recommendations [35].

Table 1. Micronutrient strategy in critically ill patients admitted to the Lausanne multidisciplinary ICU, according to disease and nutrition therapy.

\begin{tabular}{|c|c|c|c|}
\hline Situation & $\begin{array}{l}\text { Stress Profile in High Risk } \\
\text { Patients in Organ Failure * }\end{array}$ & $\begin{array}{l}\text { Parenteral Nutrition (and } \\
\text { Combined Feeding) }\end{array}$ & Enteral Nutrition \\
\hline Micro-Nutrients & $\begin{array}{l}1 \text { vial multi-trace element } \\
\text { (Addaven }{ }^{\circledR}, \text { Fresenius Kabi, } \\
\text { Oberdorf, Switzerland) } \\
+5 \text { mg Zinc } \\
+1 \text { vial multi-vitamin }\left(\text { Cernevit }{ }^{\circledR},\right. \\
\text { Baxter, Volketswil, Switzerland) } \\
+500 \text { mg vitamin } C+100 \text { mg } \\
\text { vitamin B1 }\end{array}$ & Same as stress profile & $\begin{array}{l}\text { Multi-micronutrient } \\
\text { providing DRI needs } \\
\text { (Supradyn }{ }^{\circledR}, \text { Roche, Basel, } \\
\text { Switzerland) }\end{array}$ \\
\hline Duration Route & $\begin{array}{l}\text { Diluted in } 100 \mathrm{ml} \text { de } \mathrm{NaCl} 0.9 \% \text { over } \\
6 \text { hours } \\
\text { from admission for first } 6 \text { days } \\
\text { during night shift }\end{array}$ & Daily with parenteral nutrition & $\begin{array}{l}\text { Daily } \\
\text { Mixed with enteral feeding }\end{array}$ \\
\hline
\end{tabular}

*: High risk conditions include shock (cardiogenic, septic, hypovolemic), pancreatitis, severe hepatopathy, major trauma, organ transplant, and malnutrition.

\subsection{Zinc}

Deficiencies were first identified in the 1960s [36], and have continued to plague multiple regions of the planet [37]. It has affected all ages, but particularly the elderly in western regions. Zinc deficiency affects cell-mediated immune dysfunction, susceptibility to infections, and increases oxidative stress. A randomized trial including 50 healthy elderly subjects tested the impact of a zinc-supplement $(45 \mathrm{mg}$ elemental Zn/day) orally for 12 months versus placebo [38]. First, the authors showed that compared to younger, healthy subjects, the elderly study subjects had lower plasma zinc, higher ex vivo generation of inflammatory cytokines and interleukin 10. The supplement resulted in a significant reduction of the incidence of infections and ex vivo generation of tumor necrosis factor alpha and plasma oxidative stress markers compared to the placebo group [38].

\subsection{Copper}

Deficiencies have also been shown to affect specific geographic areas-drinking water may or may not be rich in copper depending on the pipe composition. The deficiency is most frequently acquired [39], e.g., due to insufficient intakes in vulnerable populations, increased demands (pregnancy, lactation, wound healing), malabsorption (including high phytic content of vegetarian diets), increased losses (e.g., major burns, continuous renal replacement therapy), and from hereditary diseases $[40,41]$.

\subsection{Vitamin A}

Deficiency is considered the world's most important cause of preventable blindness [42]. It affected 2.8 million children under five years of age. Tragically, the numbers have only grown over the last decades [20]. 


\subsection{Vitamin $D$}

Long known only for its role in calcium and bone homeostasis, and the development of osteoporosis, its deficiency seems to be a worldwide problem, and to particularly affect inpatients. The multiple effects of vitamin D are mediated by genomic and non-genomic effects, and include muscle function and metabolism, innate and adaptive immune system, lung epithelial function, cardiac function and numerous other functions as the specific nuclear vitamin D receptor are widely expressed throughout the body [43]. As shown in Table 1, low values can be found in nearly any severe condition. Many observational studies have consistently shown an association between low vitamin D levels and poor clinical outcomes. Nevertheless, high-quality evidence showing the benefits of vitamin D supplementation in inpatients is still lacking [44]. One of the largest studies (VITdAL-ICU) was analyzed retrospectively: 475 critically ill patients with $25(\mathrm{OH}) \mathrm{D}$ levels $\leq 20 \mathrm{ng} / \mathrm{mL}$ [45]. The deficiency was not associated with persistent critical illness, nor did supplementation with vitamin D3 mitigate the development of persistent critical illness. The actual evidence does not support general vitamin D screening and supplementation for the medical inpatient population in an acute care setting [44]. By contrast, screening of chronic kidney disease patients is probably rational (see Section 3.7).

\section{Disease Specific Deficiency}

The below Table 2 summarizes the most frequent deficits encountered in the different pathologies.

Table 2. Disease specific vitamins and in trace elements deficiencies.

\begin{tabular}{ll}
\hline Disease & Micronutrients at Risk \\
\hline \multirow{2}{*}{ Alcoholism } & $\begin{array}{l}\text { Zn } \\
\text { Vitamins A, D, E, K, B12, B9, B6, B1, B2, C }\end{array}$ \\
\hline Anemia & $\begin{array}{l}\text { Fe, Cu, Co } \\
\text { Vitamins B12, B9 }\end{array}$ \\
\hline Cardiomyopathies/ Heart failure & $\begin{array}{l}\text { Se, Fe } \\
\text { Vitamin B1, D ? }\end{array}$ \\
\hline Inflammatory bowel diseases & $\begin{array}{l}\text { Se, Zn } \\
\text { Vitamins B12, A, D, E, K }\end{array}$ \\
\hline Liver diseases & $\begin{array}{l}\text { Se, Zn } \\
\text { Vitamins B12, A, D, E }\end{array}$ \\
\hline Obesity and Bariatric surgery & $\begin{array}{l}\text { Cu, Zn, Fe } \\
\text { Vitamins A, D, E, K, B1, B9, B12, C }\end{array}$ \\
\hline \multirow{2}{*}{ Kidney diseases (chronic \& acute) } & $\begin{array}{l}\text { Chronic: Vitamins K, D } \\
\text { Acute: B1, Fe, Se, Zn, Cu }\end{array}$ \\
\hline
\end{tabular}

?: means uncertainty as to deficiency.

\subsection{Alcoholism}

Micronutrient deficiencies are commonly encountered in alcoholic patients, not only explained by a decrease of global dietary intake, but also because of maldigestion, malabsorption, impaired hepatic activation and an increased breakdown and excretion. The risk of developing micro and macronutrient deficiencies has been known to increase significantly when alcohol makes up more than 30 percent of total caloric intake [46].

All fat-soluble vitamins (A, D, E and K) are susceptible to be decreased [47], although vitamins A and $\mathrm{K}$ deficiencies are more common in the case of overt hepatic disease or chronic pancreatitis. Among water soluble vitamins, the vitamin B1 (thiamine) deficiency has been the most frequently described and feared [48], potentially leading to Wernicke's encephalopathy and its well-known triad (delirium, oculomotor abnormalities and ataxia). If left untreated, it can progress to the amnestic-confabulatory syndrome called Korsakoff. The therapeutic benefit of thiamin has been demonstrated in alcoholic patients even without severe Wernicke-Korsakoff encephalopathy [49]. In the emergency department, patients with acute alcohol intoxication have not all suffered thiamine deficiency [50,51]. A systematic review showed that thiamine and vitamin $C$ were the most frequently identified deficiencies $[51,52]$. 
Nevertheless, considering the elevated prevalence of malnutrition in these patients, it is cautious and cheap, in case of hospital admission to provide 100-300 mg thiamine prior to any glucose IV infusion to prevent precipitating Wernicke's encephalopathy. Excessive alcohol consumption has also been linked to zinc and copper deficiency, which seems to be associated with a decreased quality of physical and mental life [53].

There has been one randomized trial testing the administration of $600 \mathrm{mg}$ of benfotiamine in alcohol dependent patients - this thiamine analog was associated with a reduction of alcohol consumption, but no metabolic variables were tested [54]. In the absence of other randomized trials, most of the experts advocated the empiric administration to alcohol dependent patients of multivitamin cocktails, including in particular, thiamine (200-300 mg), folic acid, vitamin B6, and vitamin C upon admission.

\subsection{Anemia}

A third of the world's population is affected by anemia, and iron deficiency is involved in $50 \%$ of the cases [18]. The most common symptoms are paleness, fatigue, dyspnea and headache. Laboratory tests have shown low blood haemoglobin concentration $(\mathrm{Hb}<130 \mathrm{~g} / \mathrm{L}$ in men, $<120 \mathrm{~g} / \mathrm{L}$ in women and $<110 \mathrm{~g} / \mathrm{L}$ in pregnancy) with microcytosis, hypochromia and serum ferritin below $30 \mu \mathrm{g} / \mathrm{L}$. Iron deficiencies can be physiological (e.g., pregnancy), or pathological in case of blood loss (e.g., surgery, trauma, digestive tract bleeding), malabsorption (e.g., celiac disease, gastrectomy), chronic disease (cancer, chronic heart failure) or in some genetic disorders [19]. In the presence of iron-deficiency anemia, investigations to identify a cause of blood loss or malabsorption are required. Preventive iron supplementation should be prescribed in at-risk patients using the oral route, while treatment of in patients with a positive diagnosis [19], may require the intravenous route due to the frequent gastric intolerance and poor absorption of oral supplements.

Macrocytic anemia can be observed in vitamin B12 or/and vitamin B9 (folate) deficiencies. Vitamin B12 deficiencies occur in cases of severe malabsorption (bariatric surgery, gastrectomy, or autoimmune gastritis), in the abuse of nitrous oxide, and in cases of inherited metabolic disorders. Vitamin B12 supply is recommended after confirmed diagnosis. This treatment will be lifelong when the etiology of the deficiency is irreversible or unknown [55].

Copper deficiencies impair the activity of hephaestin, a copper-dependent ferroxidase responsible for transporting dietary iron from intestinal enterocytes into the circulatory system-its depression leads to iron deficiencies and low hemoglobin. Copper deficiency anemia has been treated with oral or intravenous copper supplementation [56]. Cobalt, a component of hydroxycobalamin, is considered one the most stimulator of erythrocyte production. In clinical practice, Cobalt administration is rare considering the high risk of toxicity of cobalt salts in humans [57].

\subsection{Cardiomyopathies and Heart Failure}

According to the European Society of Cardiology (ESC), cardiomyopathy (CM) is defined as a myocardial disorder in which the heart muscle is structurally and functionally abnormal, in the absence of coronary artery disease, hypertension, valvular disease and congenital heart disease [58]. $\mathrm{CM}$ can lead to heart failure (HF). Deficiencies in thiamine and selenium are nutritional factors that may be involved in the occurrence of such myocardial disorders [58,59] in malnutrition conditions, malabsorption, or exclusive parenteral nutrition (PN) [60-62]. Selenium deficiency cardiomyopathy is known as the Keshan disease in humans. It was initially described in China in 1935 in selenium-poor soils, with multiple case reports. In addition to the low plasma selenium levels, low glutathione peroxidase-1 activity has been reported in animals [63]. Some cases reported have been reversible by short-term oral or IV administration, and others have been fatal [60-63].

Thiamine plays a fundamental role in cellular metabolism, especially in the carbohydrate pathway. Severe and chronic thiamine deficiencies are known as Beriberi disease. The classic presentation includes neurologic features and encephalopathy. HF symptoms have been less frequent and have been associated to metabolic acidosis and hyperlactatemia (due to an inhibition of the pyruvate 
deshydrogenase) [64,65]. A fulminant form has also been described [64]. It has been shown that about $40 \%$ of the patients hospitalized for HF presented thiamine deficiencies [66]. Animal models have demonstrated that this deficiency causes cardiac disorders (cardiac hypertrophy, depressed cardiac contractility, and dysrhythmias) in the absence of beriberi. Finally, in human studies, the benefit of thiamine supplements in cases of chronic HF are unclear [66].

Iron deficiencies in $\mathrm{HF}$ are common (about $30-50 \%$ ) in patients with chronic HF, independent of anemia, and have lead to skeletal muscle dysfunction. Recent ESC guidelines recommended screening for iron deficits in HF patients [28,59].

Recently, an association between vitamin D deficiency and HF has been suggested [67]. Vitamin D promoted cardioprotection in animals (anti-inflammatory, anti-apoptotic and anti-fibrotic mechanisms) [67].

\subsection{Inflammatory Bowel Disease}

Malnutrition is present in the vast majority of patients with inflammatory bowel disease (IBD), the deficiencies being more prevalent in Crohn's disease compared with ulcerative colitis and more important in active diseases [68]. Micronutrient deficiencies are essentially explained by the reduced dietary intake and the underlying malabsorption. They have been associated with prolonged hospitalization and higher mortality [69].

Fat-soluble vitamins are particularly prone to deficiency. A high prevalence of vitamin $\mathrm{A}$ and $\mathrm{E}$ deficiencies have been reported [70], but also of vitamin D, which has been suspected to play a role in the pathogenesis of IBD [71]. Vitamin K deficiencies are also frequent and correlated with disease activity [72].

Folate deficiencies are common in IBD and aggravated by treatment, such as sulfasalazine or methotrexate. Vitamin B12 has also been frequently observed, especially in Crohn's disease and after ileal resection of $\geq 30 \mathrm{~cm}$ [73]. Thiamin deficiency has also been reported, especially in IBD patients treated with parenteral nutrition [74].

Among trace elements, selenium deficiencies have been reported and may increase the severity of gut inflammation-the repletion data are conflicting [75]. Zinc deficiencies are also prevalent [76]. Iron deficiencies are very frequent and are the leading cause of anemia in patients with IBD. In the presence of inflammation, this diagnosis can be challenging and relies on the values of serum ferritin values.

\subsection{Liver Disease}

The liver plays a crucial role in maintaining systemic $\mathrm{Zn}$ homeostasis [77]. Chronic liver disease, such as chronic hepatitis, liver cirrhosis, or fatty liver, impairs Zn metabolism, and has resulted in Zn deficiency, which in turn has caused multiple metabolic abnormalities, including insulin resistance, hepatic steatosis and hepatic encephalopathy. Zn deficiency may also favor carcinogenesis of hepatocellular carcinoma (HCC). In chronic liver disease, low levels of selenium [78] have been generally observed. In comparison, copper levels have often been elevated [79]. It is argued that doses required to achieve an effect in chronic hepatitis are far beyond DRI with 150-200 mg/day [80].

In cases of liver disease secondary to alcoholism, please see 3.1 (same picture). Group B vitamin deficiencies, especially thiamine, are common in cirrhosis [81]. Unlike observations for alcoholic patients without liver disease, vitamin B12 levels have been frequently elevated in viral hepatitis, cirrhosis and hepatocellular carcinoma (HCC) [82]. This increase has been explained by the cytolysis of hepatocytes, and vitamin B12 being mainly stored in the liver.

Fat-soluble vitamin deficiencies have been observed in cases of alcoholism, but also in cholestasis with malabsorption and bile salt deficiency [83]. Levels of vitamins A, D and E should therefore be routinely checked as well as prothrombin time. However, prolonged prothrombin time does not purely reflect vitamin $\mathrm{K}$ deficiencies, but also reduced levels of coagulation factor V. Importantly, vitamin $\mathrm{D}$ has pleiotropic effects for liver disease, including anti-inflammatory, immune-modulatory and anti-fibrotic properties in addition to its classical skeletal effects. This may impact on disease 
progression [84], especially in HCC and non-alcoholic steatohepatitis, although any benefit from its repletion has not been formally proven by prospective studies [85].

\subsection{Obesity \& Bariatric Surgery}

In patients with grade III obesity (body mass index $\geq 40 \mathrm{~kg} \cdot \mathrm{m}^{-2}$ or $\geq 35 \mathrm{~kg} \cdot \mathrm{m}^{-2}$ with comorbid conditions), bariatric surgery has become common. In 2013, over 450,000 bariatric surgeries were performed worldwide. Roux-en-Y gastric bypass, adjustable gastric band, and sleeve gastrectomy were the most frequent procedures [86,87]. Micronutrient deficiencies were observed before (in obese patients, vitamin C deficiency in about $40 \%$ and zinc deficiency is up to $50 \%$ ) and after the surgery. Due to fat malabsorption and maldigestion, all fat-soluble vitamins are at risk. The bypass of the duodenum and proximal jejunum lead to thiamine deficiencies [86], leading to a risk of clinical Wernicke's encephalopathy [88]. Vitamin B9 is approximately 10\%. Vitamin B12 deficiencies have been widely described in the literature because of their neurologic complications, especially an acquired myelopathy with paresthesias, ataxia and muscle weakness [89]. It is recalled that the intrinsic factor produced in the stomach is needed for ileal absorption of vitamin B12. The severity of a vitamin B6 deficiencies vary from peripheral neuropathy to seizures [89]. The common trace elements deficiencies after bariatric surgery include copper (absorbed in the stomach and the duodenum), iron (absorbed in the duodenum), and zinc (absorbed in the jejunum). The prevalence of copper deficiency has been reported to be as high as $90 \%$ post- surgery ( $70 \%$ for zinc). Further, systematic supplements of micronutrients are recommended after bariatric surgery by the American Society for Parenteral and Enteral Nutrition (ASPEN) [86] and the American Society for Metabolic and Bariatric Surgery clinical practice guidelines (ASMBS) [90].

\subsection{Kidney Disease}

Kidney disease, whether chronic (CKD) or acute, affects micronutrient homeostasis and might lead to either deficiency or toxic excess. Indeed, a decreased glomerular filtration rate might lead to accumulation of molecules normally excreted by the kidney such as selenium. On the other hand, renal replacement therapy when applied might lead to uncompensated losses of other micronutrients (copper). Finally, the loss of renal activation might lead to decreased biological activity (vitamin D). Unfortunately, the authors knowledge remains limited [91].

Anemia is commonly observed in CKD. Beyond the lack of erythropoietin, which is now clearly established and easily administered, it might also be associated with alterations in iron metabolism and inflammation. Oral corrections of iron deficiencies in pre-dialysis CKD patients have been shown to be an efficient option in a recent randomized trial [92]. The role of hepcidin, a key regulator of circulating iron level in CKD associated anemia is increasingly recognized. Indeed, the condition has been associated with elevated hepcidin serum levels as it is typically excreted by the kidney [93]. This leads to reduced iron availability and anemia. Its measurement and potential anti-hepcidin therapies could help managing anemia in CKD $[27,94]$.

Subclinical vitamin $\mathrm{K}$ deficiencies have been shown to be clinically relevant as requirements have increased due to the vitamin K-dependent proteins required to inhibit calcification [95]. This vitamin governs the gamma-carboxylation of matrix Gla protein for inhibiting vascular calcification, and the vitamin D binding protein receptor is related to vitamin K gene expression [96]. Deficiency may favor vascular calcification.

Chronic dialysis is typically associated with elevated oxidative stress leading to low levels of zinc, selenium and GPX. A French team showed three decades ago that weekly administration of selenium with zinc was able to restore GPX activity and reduced thiobarbituric acid reactants (TBARs) plasma concentrations [97]. In a large cohort of 1278 patients on incident hemodialysis, it was observed that lower selenium and zinc concentrations were strongly and independently associated with death and all-cause hospitalization [98]. Trimestrial monitoring of selenium and zinc may thus be justified, with repletion in case of low values. 
In acute kidney failure requiring continuous renal replacement therapy, other micronutrients such as thiamine and copper will be lost in the effluent fluid [39,40,99]. Copper losses causing low blood levels can be associated with severe arrhythmias and wound healing complications. Very low plasma levels $(<8 \mathrm{mmol} / \mathrm{L})$ might require active intravenous repletion with doses $6-10 \mathrm{mg} /$ day, i.e., $5-10$ times the usual DRI [40].

\subsection{Migrant Populations}

Being a migrant is not a disease, but a difficult social condition frequently associated with malnutrition for multiple reasons ranging from insufficient food intake, to exposure to unusual food or unbalanced diet due to incapacity to find the traditional foods. Migrants represent a growing category of inpatients. Micronutrients of concern have shown to be retinol, vitamin D, magnesium, potassium, copper, and selenium [11], in addition to iron.

\subsection{Laboratory Investigations}

Laboratory investigations of micronutrient deficiencies have often not been systematic except for 2 conditions: (1) Anemia outwork, which generally included determination of blood Vitamin B6, B12, iron, ferritin and transferrin; (2) screening before and the follow-up after bariatric surgery included thiamine, vitamin B12, folic acid, iron, zinc, copper, calcium and the liposoluble vitamins D, A, E and $\mathrm{K}$ were recommended [90]. In other conditions, the diagnosis lacked standardization. A pragmatic approach upon admission or during hospitalization could be to draw an additional blood sample for further diagnostic outwork, and to empirically administer multi-micronutrients without delay.

Inflammation causes a redistribution of micronutrients between the various compartments and generally reduces circulating levels. The intensity of inflammation has been reflected by CRP levels [24]. The example of vitamin D has been emblematic. While a CRP $>80 \mathrm{mg} / \mathrm{L}$ has been associated with a reduction of its blood concentration by $40 \%$ below reference ranges [24], CRP has never been mentioned in the vitamin D trials. CRP should belong to any micronutrients outwork as low levels do not necessarily indicate a deficiency.

\section{Micronutrient Unavailability as Cause of Deficiency}

\subsection{Nutritional Sources}

Hospital related malnutrition is a well know entity that is observed worldwide and is related to being bedridden [100]. A large proportion of patients only consume a third or half of the proposed meals [4]. In our hospital, a standard daily serving provides 1700-1800 kcal. If only half is consumed, the daily micronutrients cannot be covered.

The sickest patients are fed with enteral nutrition. Due to regulatory constraints, the industry must respect micronutrient recommendations intended for the general healthy population, the previously mentioned DRI. The concentrations of the products are calculated for feeding doses varying between 1500 and $2500 \mathrm{kcal} /$ day. However, worldwide it has been shown that many patients receive no more than $1000 \mathrm{kcal} /$ day by this route [101]. In addition, the most recent nutrition guidelines for critical care patients recommended ramping up the feeding over several days [102]. The consequences might be an even further reduction of nutrition delivery. By design, the enteral feeding solutions will not be able to cover needs as long as quantities below $1500 \mathrm{kcal}$ per day are provided. Table 3 shows the detailed micronutrient provision for $1000 \mathrm{kcal} /$ day provided by the 10 most frequently used enteral feeding solutions provided by 4 international companies on the Swiss market. While intakes below DRI of fluor and iodine may be less important during an acute phase, low intakes of iron and of the B vitamin group are a concern considering their essential role in energy (ATP synthesis) and carbohydrate metabolism. Moreover, as absorption is unreliable and as needs might be higher, several micronutrients such as vitamin $C$ are just in the reference range, which may be insufficient. 
Table 3. Energy, protein and micronutrient data for $1000 \mathrm{kcal}$ for a selection of frequent products available on the Swiss market compared to the dietary reference intakes (DRI). The values which are below the DRI appear in red and bold characters; in violet-bold, those for which DRI is just covered.

\begin{tabular}{|c|c|c|c|c|c|c|c|c|c|c|c|}
\hline & Abbott & Abbott & Nestlé & Nestlé & Nestlé & Fresenius K & Fresenius K & Fresenius K & Nutricia & Nutricia & \\
\hline Values for $1000 \mathrm{kcal}$ & $\begin{array}{l}\text { Promote } \\
\text { Fibres Plus }\end{array}$ & Jevity Plus & $\begin{array}{l}\text { NovaSource GI } \\
\text { Advance }\end{array}$ & $\begin{array}{l}\text { Isosource } \\
\text { Energy }\end{array}$ & $\begin{array}{l}\text { Peptamen } \\
\text { Intense }\end{array}$ & $\begin{array}{l}\text { Fresubin } 2 \\
\text { kcal HP }\end{array}$ & $\begin{array}{l}\text { Fresubin } \\
\text { HP Energy }\end{array}$ & $\begin{array}{l}\text { Fresubin } \\
\text { Intensive }\end{array}$ & $\begin{array}{l}\text { Nutrison } \\
\text { Protein + Mulitf }\end{array}$ & Nutrison & $\begin{array}{l}\text { DRI } \\
\text { Adults }\end{array}$ \\
\hline $\begin{array}{l}\text { Energy density } \mathrm{kcal} / \mathrm{ml} \\
\text { Proteins } \mathrm{g} / 1000 \mathrm{kcal}\end{array}$ & $\begin{array}{l}1.3 \\
62.5\end{array}$ & $\begin{array}{l}1.2 \\
46.3\end{array}$ & $\begin{array}{l}1.55 \\
61.9\end{array}$ & $\begin{array}{l}1.57 \\
38.9\end{array}$ & $\begin{array}{l}1.0 \\
93.0\end{array}$ & $\begin{array}{l}2.0 \\
50.0\end{array}$ & $\begin{array}{l}1.5 \\
50.0\end{array}$ & $\begin{array}{l}1.2 \\
83.3\end{array}$ & $\begin{array}{l}1.3 \\
492\end{array}$ & 1.0 & \\
\hline & & 40.5 & & & & & 50.0 & 83.3 & 49.2 & 40.0 & \\
\hline Fer $(\mathrm{Fe}) \mathrm{mg}$ & 12.3 & 15.0 & 11.0 & 10.2 & 16.0 & 13.5 & 8.7 & 16.7 & 15.6 & 16.0 & 18 \\
\hline Zinc (Zn) $\mathrm{mg}$ & 13.1 & 11.7 & 11.6 & 9.6 & 13 & 12 & 8.0 & 12.5 & 11.7 & 12 & 8 \\
\hline Cuivre $(\mathrm{Cu}) \mathrm{mg}$ & 1.5 & 1.7 & 1.5 & 1.5 & 1.8 & 1.5 & 0.7 & 1.7 & 1.8 & 1.8 & 0.9 \\
\hline Manganèse (Mn) mg & 3.1 & 3.5 & 2.3 & 2.3 & 1.4 & 2.5 & 2.0 & 4.2 & 3.2 & 3.3 & 1.8 \\
\hline Fluor & 0.0 & 0.0 & 1.0 & 1.3 & 1.6 & 1.5 & 0.7 & 1.7 & 1.0 & 1.0 & 3 \\
\hline Iode (I) $\mu \mathrm{g}$ & 123 & 125 & 142 & 146 & 120 & 134 & 89 & 183 & 102 & 130 & 150 \\
\hline Molybdène (Mo) $\mu \mathrm{g}$ & 92 & 108 & 116 & 115 & 170 & 100 & 67 & 117 & 102 & 100 & 45 \\
\hline Chrome (Cr) $\mu \mathrm{g}$ & 54 & 67 & 97 & 96 & 60 & 67 & 45 & 92 & 65 & 67 & 20 \\
\hline Selenium (Se) $\mu \mathrm{g}$ & 65 & 63 & 65 & 64 & 80 & 67 & 45 & 88 & 55 & 57 & 55 \\
\hline $\mathrm{A}(\mathrm{RE}) \mu \mathrm{g}$ & 1154 & 700 & 1097 & 1083 & 650 & 925 & 613 & 1500 & 797 & 820 & 750 \\
\hline $\mathrm{D} \mu \mathrm{g}$ & 6.9 & 8.3 & 14.2 & 14 & 14 & 10 & 8.7 & 17 & 13.3 & 10 & 10 \\
\hline $\mathrm{E}(\alpha-\mathrm{TE}) \mathrm{mg}$ & 18.2 & 20 & 17.4 & 16.6 & 14 & 13.5 & 8.7 & 25 & 12.5 & 13 & 15 \\
\hline $\mathrm{K} \mu \mathrm{g}$ & 54 & 67 & 71 & 76 & 44 & 67 & 45 & 75 & 52 & 53 & 90 \\
\hline $\mathrm{Cmg}$ & 154 & 100 & 123 & 102 & 80 & 67 & 45 & 183 & 102 & 100 & 75 \\
\hline B1 mg & 1.5 & 1.6 & 1.6 & 1.5 & 1.0 & 1.5 & 0.7 & 1.7 & 1.5 & 1.5 & 1.1 \\
\hline B2 Riboflavin mg & 2.2 & 1.8 & 1.7 & 1.7 & 1.3 & 2.0 & 1.3 & 1.7 & 1.6 & 1.6 & 1.1 \\
\hline B3 Niacin mg & 21.5 & 18.3 & 20.0 & 17.2 & 30 & 16 & 11 & 20 & 18 & 18 & 14 \\
\hline B5 Pantothenic acid mg & 7.7 & 8.3 & 5.2 & 5.5 & 4.5 & 4.5 & 3.3 & 7.5 & 5.2 & 5.3 & 5 \\
\hline B6 Pyridoxin mg & 2.2 & 2.2 & 1.8 & 1.8 & 1.7 & 1.5 & 0.8 & 2.5 & 1.6 & 1.7 & 1.5 \\
\hline B12 Cyancobalamin $\mu \mathrm{g}$ & 4.6 & 2.9 & 3.8 & 3.7 & 2.9 & 2.5 & 2.0 & 4.2 & 2.0 & 2.1 & 2.4 \\
\hline B9 Folic acid $\mu \mathrm{g}$ & 231 & 250 & 290 & 287 & 300 & 267 & 180 & 263 & 258 & 270 & 400 \\
\hline B8 Biotin $\mu \mathrm{g}$ & 46 & 43 & 45 & 45 & 30 & 50 & 33 & 57 & 39 & 40 & 30 \\
\hline Choline mg & 462 & 500 & 368 & 382 & 670 & 0 & 178 & 0 & 359 & 370 & 425 \\
\hline
\end{tabular}


Regarding these low micronutrient doses, it might be justified to deliver standard multivitamin and trace element products daily providing DRI doses to the majority of inpatients. This strategy has been applied for many years in the Lausanne university hospital's ICU, as critically ill patients do have higher needs. In the sickest patients, multi-micronutrients cocktails have been delivered IV for the first 5 days [33], resulting in a shortening of the hospital stay, particularly in major trauma patients.

\subsection{Geriatric Population}

The qualification, elderly, encompasses patients aged 60 to over 100 years. While the younger seniors often are fit until the seventies, some physiological changes already occur that become exacerbated with growing age. The elderly often present with anorexia which is considered a complex geriatric syndrome and a risk factor for frailty [9]. These changes are associated with lower weight, and lower energy expenditure. The body undergoes specific changes-the gastric mucosa tends to atrophy, reducing vitamin B12 absorption. Indeed, the decline in vitamin B12 is independent of nutrition but caused by a decline of both the intestinal uptake and the renal reabsorption system for vitamin B12 [103]. The elderly also require higher doses of vitamin $\mathrm{B} 6$ and $\mathrm{D}$ to maintain health, which has been integrated into DRI recommendations for older subjects. Deficiencies can be overcome by supplementation, as shown by a large randomized controlled trial including 652 geriatric patients-daily oral nutrition supplements enriched with proteins, hydroxy-methyl-butyrate, vitamin D and other micronutrients reduced mortality [104].

\subsection{Partial or Complete Starving upon Hospital Admission and Refeeding}

The incidence and importance of the refeeding has often been underestimated [105]. The absence of a uniform definition participates in its underestimation [105]. Refeeding syndrome consists of metabolic changes that occur on the reintroduction of food or simply a glucose infusion. A few days of feeding grossly below needs will be sufficient to create the metabolic crisis which is characterized by sudden shifts in the electrolytes that are needed for energy and substrate (mainly glucose) metabolism. The NutritionDay survey, an initiative that analysed the relation between nutritional intakes and outcomes of a wide range of institutionalized and hospitalized patients worldwide, has shown that more than half of the patients admitted to hospital were eating less than half of their normal food intake before admission [106]. This places the majority of hospitalized patients at risk of a refeeding syndrome.

Some categories of patients, such as chronic, alcohol consumers, which are largely prevalent in western countries, being present in nearly $30 \%$ of hospital admissions, are at higher risk of thiamine deficiencies-these patients are at particularly high risk of refeeding syndrome and its worst neurologic complication, the Wernicke encephalopathy. A recent review of the literature confirmed the importance of administering intravenous thiamine to these patients in order to prevent severe sequelae [107]. The recommended doses ranged from $50-100 \mathrm{mg} /$ day to $250-500 \mathrm{mg} 3$ times a day. The IV route was recommended due to the frequent presence of gastritis in these patients, which reduced absorption.

\subsection{Economic Considerations}

A Canadian prospective cohort study showed that approximately $40 \%$ of the 956 patients admitted to hospital were moderately to severely malnourished. These patients had longer hospital stays, and as a result, cost more than the well-nourished patients [108]. A European narrative review showed that malnutrition increased the length of hospital stays by 2.4 to 7.2 days [5]. Malnutrition led to an additional individual cost ranging between $1640 €$ and $5829 €$.

Clinical evidences are lacking for empirical multi-micronutrient supplements. The cost of malnutrition attributable to micronutrient deficiencies have not been assessed in adult inpatients and several studies have failed to demonstrate significant beneficial effects of various micronutrient supplements in the general population [109]. Nevertheless, there are data suggesting a benefit, at least in the sickest patients $[33,110]$. 
However, data exists for children. A study focusing on estimates of disability-adjusted life years and their monetization showed that short-term economic costs of micronutrient malnutrition in India amounted to $0.8 \%$ to $2.5 \%$ of the gross domestic product [14]. The health and cost consequences of iodine, iron, vitamin A, and zinc deficiencies were assessed in Pakistani children: Societal costs amounted to $1.44 \%$ of gross domestic product and $4.45 \%$ of disability-adjusted life-years in Pakistan in 2013, which hindered the country's development [111].

When deciding about an empirical administration of micronutrients, the analytical costs of deficiency diagnosis must be considered. The European Society for Clinical Nutrition and Metabolism (ESPEN) monitoring recommendations indicate that some vitamin and trace element analysis (inductively coupled plasma mass spectrometry: ICP-MS) are expensive [112]. They are actually more expensive than the empirical administration. A semi-automatic weekly determination of blood selenium levels in our ICU resulted in major costs that could be contained by the decision to let blood sampling be prescribed only by the ICU nutritionists and dieticians in patients at risk [113].

A multi-micronutrient tablet costs $0.80 €$ (the IV dose in Table 1 costs $25 €$ ), which is negligible compared to the cost of one day in hospital, or worse, in the ICU. This prescription is likely to be beneficial if the administration is standardized, and limited to the first week of hospitalization, and to patients on enteral feeding.

\section{Conclusions}

Micronutrient deficiencies and borderline status are more frequent than generally acknowledged. The most important potential acute deficiency that may compromise outcome is thiamine deficiency. Other deficiencies will impact on immune defenses and anabolic capacity. Therefore, an empirical and cheap complementation strategy, based on daily oral multi-micronutrient products providing DRI, may be justified for hospital inpatients for one week. It is important to state that the evidence from trials is still missing.

Author Contributions: Conceptualization M.M.B.; Search methodology M.M.B., N.B.-H., O.P.; validation, M.M.B., O.P., A.S. and N.B.-H.; writing-original draft preparation, M.M.B., O.P., N.B.-H.; writing-review and editing, N.B.-H., O.P., A.S., and M.M.B.

Conflicts of Interest: None of the authors have any conflicts of interest to declare.

\section{Abbreviations}

$\begin{array}{ll}\text { DRI } & \text { Dietary Reference Intakes } \\ \text { CKD } & \text { Chronic kidney disease } \\ \text { CM } & \text { cardiomyopathy } \\ \text { CRP } & \text { C-reactive protein } \\ \text { ESC } & \text { European Society of Cardiology } \\ \text { ESPEN } & \text { European Society for Clinical Nutrition and Metabolism } \\ \text { GPX } & \text { Glutathione peroxidase } \\ \text { HF } & \text { Heat failure } \\ \text { IBD } & \text { inflammatory bowel disease } \\ \text { IV } & \text { Intravenous } \\ \text { RDA } & \text { recommended daily allowance }\end{array}$

\section{References}

1. Cederholm, T.; Jensen, G.L.; Correia, M.I.T.D.; Gonzalez, M.C.; Fukushima, R.; Higashiguchi, T.; Baptista, G.; Barazzoni, R.; Blaauw, R.; Coats, A.; et al. GLIM criteria for the diagnosis of malnutrition-A consensus report from the global clinical nutrition community. Clin. Nutr. 2019, 38, 1-9. [CrossRef] [PubMed] 
2. Allen, L.; de Benoist, B.; Dary, O.; Hurrel, R. Guidelines on food fortification with micronutrients. In World Health Organization (WHO) Food and Agricultural Organization (FAO) of the United Nations; WHO: Geneva, Switzerland, 2006; pp. 1-376. Available online: http://www.who.int/nutrition/publications/guide_food_ fortification_micronutrients.pdf (accessed on 25 June 2019).

3. Trumbo, P.; Yates, A.; Schlicker, S.; Poos, M. Dietary reference intakes: Vitamin A, vitamin K, arsenic, boron, chromium, copper, iodine, iron, manganese, molybdenum, nickel, silicon, vanadium, and zinc. J. Am. Diet. Assoc. 2001, 101, 294-301. [CrossRef]

4. Schuetz, P.; Fehr, R.; Baechli, V.; Geiser, M.; Deiss, M.; Gomes, F.; Kutz, A.; Tribolet, P.; Bregenzer, T.; Braun, N.; et al. Individualised nutritional support in medical inpatients at nutritional risk: A randomised clinical trial. Lancet 2019, 393, 2312-2321. [CrossRef]

5. Khalatbari-Soltani, S.; Marques-Vidal, P. The economic cost of hospital malnutrition in Europe; a narrative review. Clin. Nutr. ESPEN 2015, 10, e89-e94. [CrossRef] [PubMed]

6. Norman, K.; Pichard, C.; Lochs, H.; Pirlich, M. Prognostic impact of disease-related malnutrition. Clin. Nutr. 2008, 27, 5-15. [CrossRef] [PubMed]

7. Pawellek, I.; Dokoupil, K.; Koletzko, B. Prevalence of malnutrition in paediatric hospital patients. Clin. Nutr. 2008, 27, 72-76. [CrossRef] [PubMed]

8. Orlandoni, P.; Venturini, C.; Jukic Peladic, N.; Costantini, A.; Di Rosa, M.; Cola, C.; Giorgini, N.; Basile, R.; Fagnani, D.; Sparvoli, D.; et al. Malnutrition upon Hospital Admission in Geriatric Patients: Why Assess It? Front. Nutr. 2017, 4, 50. [CrossRef]

9. Sanford, A.M. Anorexia of aging and its role for frailty. Curr. Opin. Clin. Nutr. Metab. Care 2017, $20,54-60$. [CrossRef]

10. World Health Organisation. In Nutrition for Health and Development: A Global Agenda for Combating Malnutrition; Docemunt WHO/NHD/00.6; WHO: Geneva, Switzerland, 2000.

11. Castaneda-Gameros, D.; Redwood, S.; Thompson, J. Nutrient Intake and Factors Influencing Eating Behaviors in Older Migrant Women Living in the United Kingdom. Ecol. Food Nutr. 2018, 57, 50-68. [CrossRef]

12. Black, R. Global distribution and disease burden related to micronutrient deficiencies. Nestle Nutr. Inst. Workshop Ser. 2014, 78, 21-28. [CrossRef]

13. White, J.; Zasoski, R. Mapping soil micronutrients. Field Crop. Res. 1999, 60, 11-26. [CrossRef]

14. Stein, A.; Qaim, M. The human and economic cost of hidden hunger. Food Nutr. Bull. 2007, 28, 125-134. [CrossRef] [PubMed]

15. Diaz, J.; de las Cagigas, A.; Rodriguez, R. Micronutrient deficiencies in developing and affluent countries. Eur. J. Clin. Nutr. 2003, 57 (Suppl. 1), S70-S72. [CrossRef]

16. World Health Orgniasation. Micronutrients. Available online: https://www.who.int/nutrition/topics/ micronutrients/en/ (accessed on 25 April 2019).

17. Zimmermann, M.B.; Boelaert, K. Iodine deficiency and thyroid disorders. Lancet Diabetes Endocrinol. 2015, 3, 286-295. [CrossRef]

18. Stoltzfus, R. Defining iron-deficiency anemia in public health terms: A time for reflection. J. Nutr. 2001, 131, 565S-567S. [CrossRef] [PubMed]

19. Lopez, A.; Cacoub, P.; Macdougall, I.; Peyrin-Biroulet, L. Iron deficiency anaemia. Lancet 2016, 367, $907-917$. [CrossRef]

20. Camaschella, C. Iron deficiency. Blood 2019, 133, 30-39. [CrossRef] [PubMed]

21. Schuepbach, R.; Bestmann, L.; Bechir, M.; Fehr, J.; Bachli, E. High prevalence of Iron deficiency among educated hospital employees in Switzerland. Int. J. Biomed. Sci. IJBS 2011, 7, 150-157.

22. Heming, N.; Montravers, P.; Lasocki, S. Iron deficiency in critically ill patients: Highlighting the role of hepcidin. Crit. Care 2011, 15, 210. [CrossRef]

23. Lasocki, S.; Piednoir, P.; Couffignal, C.; Rineau, E.; Dufour, G.; Lefebvre, T.; Puy, H.; Duval, X.; Driss, F.; Schilte, C. Does IV Iron Induce Plasma Oxidative Stress in Critically Ill Patients? A comparison with healthy volunteers. Crit. Care Med. 2016, 44, 521-530. [CrossRef]

24. Duncan, A.; Talwar, D.; McMillan, D.; Stefanowicz, F.; O’Reilly, D. Quantitative data on the magnitude of the systemic inflammatory response and its effect on micronutrient status based on plasma measurements. Am. J. Clin. Nutr. 2012, 95, 64-71. [CrossRef] [PubMed] 
25. Galesloot, T.E.; Vermeulen, S.H.; Geurts-Moespot, A.J.; Klaver, S.M.; Kroot, J.; van Tienoven, D.; Wetzels, J.F.; Kiemeney, L.; Sweep, F.C.; den Heijer, M.; et al. Serum hepcidin: Reference ranges and biochemical correlates in the general population. Blood 2011, 117, e218-e225. [CrossRef] [PubMed]

26. Johnson-Wimbley, T.D.; Graham, D.Y. Diagnosis and management of iron deficiency anemia in the 21st century. Ther. Adv. Gastroenterol. 2011, 4, 177-184. [CrossRef] [PubMed]

27. Ueda, N.; Takasawa, K. Impact of Inflammation on Ferritin, Hepcidin and the Management of Iron Deficiency Anemia in Chronic Kidney Disease. Nutrients 2018, 10, 1173. [CrossRef] [PubMed]

28. Cohen-Solal, A.; Leclercq, C.; Deray, G.; Lasocki, S.; Zambrowski, J.; Mebazaa, A.; de Groote, P.; Damy, T.; Galinier, M. Iron deficiency: An emerging therapeutic target in heart failure. Heart 2014, 100, 1414-1420. [CrossRef]

29. Vinceti, M.; Filippini, T.; Wise, L.A. Environmental Selenium and human health: An update. Curr. Environ. Health Rep. 2018, 5, 464-485. [CrossRef] [PubMed]

30. Jones, G.D.; Droz, B.; Greve, P.; Gottschalk, P.; Poffet, D.; McGrath, S.P.; Seneviratne, S.I.; Smith, P.; Winkel, L.H. Selenium deficiency risk predicted to increase under future climate change. Proc. Natl. Acad. Sci. USA 2017, 114, 2848-2853. [CrossRef]

31. Rayman, M.P. Selenium and human health. Lancet 2012, 379, 1256-1268. [CrossRef]

32. Alhazzani, W.; Jacobi, J.; Sindi, A.; Hartog, C.; Reinhart, K.; Kokkoris, S.; Gerlach, H.; Andrews, P.; Drabek, T.; Manzanares, W.; et al. The effect of selenium therapy on mortality in patients with sepsis syndrome: A systematic review and meta-analysis of randomized controlled trials. Crit. Care Med. 2013, 41, 1555-1564. [CrossRef]

33. Berger, M.M.; Soguel, L.; Shenkin, A.; Revelly, J.P.; Pinget, C.; Baines, M.; Chiolero, R.L. Influence of early antioxidant supplements on clinical evolution and organ function in critically ill cardiac surgery, major trauma and subarachnoid hemorrhage patients. Crit. Care 2008, 12, R101. [CrossRef]

34. Bloos, F.; Trips, E.; Nierhaus, A.; Briegel, J.; Heyland, D.K.; Jaschinski, U.; Moerer, O.; Weyland, A.; Marx, G.; Grundling, M.; et al. Effect of sodium selenite administration and procalcitonin-guided therapy on mortality in patients with severe sepsis or septic shock: A randomized clinical trial. JAMA Intern. Med. 2016, 176, 1266-1276. [CrossRef] [PubMed]

35. Rhodes, A.; Evans, L.E.; Alhazzani, W.; Levy, M.M.; Antonelli, M.; Ferrer, R.; Kumar, A.; Sevransky, J.E.; Sprung, C.L.; Nunnally, M.E.; et al. Surviving Sepsis Campaign: International Guidelines for Management of Sepsis and Septic Shock: 2016. Intensive Care Med. 2017, 43, 304-377. [CrossRef] [PubMed]

36. Prasad, A.S. Zinc deficiency. BMJ 2003, 326, 409-410. [CrossRef] [PubMed]

37. Prasad, A.S. Impact of the discovery of human zinc deficiency on health. J. Trace Elem. Med. Biol. 2014, 28, 357-363. [CrossRef] [PubMed]

38. Prasad, A.S.; Beck, F.W.; Bao, B.; Fitzgerald, J.T.; Snell, D.C.; Steinberg, J.D.; Cardozo, L.I. Zinc supplementation decreases incidence of infections in the elderly: Effect of zinc on generation of cytokines and oxidative stress. Am. J. Clin. Nutr. 2007, 85, 837-844. [CrossRef] [PubMed]

39. Altarelli, M.; Ben-Hamouda, N.; Schneider, A.; Berger, M.M. Copper Deficiency-Causes, Manifestations, and Treatment. Nutr. Clin. Prac. 2019. [CrossRef] [PubMed]

40. Ben-Hamouda, N.; Charrière, M.; Voirol, P.; Berger, M.M. Massive copper and selenium losses cause life-threatening deficiencies during prolonged continuous renal replacement. Nutrition 2017, 34, 71-75. [CrossRef] [PubMed]

41. Wapnir, R.A. Copper absorption and bioavailability. Am. J. Clin. Nutr. 1998, 67, 1054S-1060S. [CrossRef] [PubMed]

42. World Health Organization. The Global Burden of Disease: 2004 Update. 1. Cost of Illness. 2. World Health—Statistics. 3. Mortality—Trends. Available online: http://www.who.int/healthinfo/global_burden_ disease/GBD_report_2004update_full.pdf (accessed on 30 August 2012).

43. Amrein, K.; Papinutti, A.; Mathew, E.; Vila, G.; Parekh, D. Vitamin D and critical illness: What endocrinology can learn from intensive care and vice versa. Endocr. Connect. 2018, 7, R304-R315. [CrossRef] [PubMed]

44. Gradel, L.; Merker, M.; Mueller, B.; Schuetz, P. Screening and Treatment of Vitamin D Deficiency on Hospital Admission: Is There a Benefit for Medical Inpatients? Am. J. Med. 2016, 129, 116.e111-116.e134. [CrossRef] [PubMed] 
45. Viglianti, E.M.; Zajic, P.; Iwashyna, T.J.; Amrein, K. Neither vitamin D levels nor supplementation are associated with the development of persistent critical illness: A retrospective cohort analysis. Crit. Care Resusc. 2019, 21, 39-44. [PubMed]

46. Lieber, C.S. Alcohol: Its metabolism and interaction with nutrients. Annu. Rev. Nutr. 2000, 20, 395-430. [CrossRef] [PubMed]

47. Leo, M.A.; Lieber, C.S. Alcohol, vitamin A, and beta-carotene: Adverse interactions, including hepatotoxicity and carcinogenicity. Am. J. Clin. Nutr. 1999, 69, 1071-1085. [CrossRef] [PubMed]

48. Leevy, C.M. Thiamin deficiency and alcoholism. Ann. N. Y. Acad. Sci. 1982, 378, 316-326. [CrossRef] [PubMed]

49. Ambrose, M.L.; Bowden, S.C.; Whelan, G. Thiamin treatment and working memory function of alcohol-dependent people: Preliminary findings. Alcohol. Clin. Exp. Res. 2001, 25, 112-116. [CrossRef] [PubMed]

50. Li, S.F.; Jacob, J.; Feng, J.; Kulkarni, M. Vitamin deficiencies in acutely intoxicated patients in the ED. Am. J. Emerg. Med. 2008, 26, 792-795. [CrossRef]

51. Lee, H.J.; Shin, J.; Hong, K.; Jung, J.H. Vitamin C deficiency of Korean homeless vatients visiting to Emergency Department with acute alcohol intoxication. J. Korean Med Sci. 2015, 30, 1874-1880. [CrossRef]

52. Ijaz, S.; Jackson, J.; Thorley, H.; Porter, K.; Fleming, C.; Richards, A.; Bonner, A.; Savovic, J. Nutritional deficiencies in homeless persons with problematic drinking: A systematic review. Int. J. Equity Health 2017, 16, 71. [CrossRef]

53. Ordak, M.; Bulska, E.; Jablonka-Salach, K.; Luciuk, A.; Maj-Zurawska, M.; Matsumoto, H.; Nasierowski, T.; Wojnar, M.; Matras, J.; Muszynska, E.; et al. Effect of Disturbances of Zinc and Copper on the Physical and Mental Health Status of Patients with Alcohol Dependence. Biol. Trace Elem. Res. 2018, 183, 9-15. [CrossRef]

54. Manzardo, A.M.; He, J.; Poje, A.; Penick, E.C.; Campbell, J.; Butler, M.G. Double-blind, randomized placebo-controlled clinical trial of benfotiamine for severe alcohol dependence. Drug Alcohol. Depend. 2013, 133, 562-570. [CrossRef]

55. Green, R. Vitamin B12 deficiency from the perspective of a practicing hematologist. Blood 2017, 129, $2603-2611$. [CrossRef] [PubMed]

56. Myint, Z.W.; Oo, T.H.; Thein, K.Z.; Tun, A.M.; Saeed, H. Copper deficiency anemia: Review article. Ann. Hematol. 2018, 97, 1527-1534. [CrossRef] [PubMed]

57. Oliveira, D.C.; Nogueira-Pedro, A.; Santos, E.W.; Hastreiter, A.; Silva, G.B.; Borelli, P.; Fock, R.A. A review of select minerals influencing the haematopoietic process. Nutr. Res. Rev. 2018, 31, 267-280. [CrossRef] [PubMed]

58. Elliott, P.; Andersson, B.; Arbustini, E.; Bilinska, Z.; Cecchi, F.; Charron, P.; Dubourg, O.; Kuhl, U.; Maisch, B.; McKenna, W.J.; et al. Classification of the cardiomyopathies: A position statement from the European Society Of Cardiology Working Group on Myocardial and Pericardial Diseases. Eur. Heart J. 2008, 29, 270-276. [CrossRef] [PubMed]

59. Ponikowski, P.; Voors, A.A.; Anker, S.D.; Bueno, H.; Cleland, J.G.F.; Coats, A.J.S.; Falk, V.; Gonzalez-Juanatey, J.R.; Harjola, V.P.; Jankowska, E.A.; et al. 2016 ESC Guidelines for the diagnosis and treatment of acute and chronic heart failure: The Task Force for the diagnosis and treatment of acute and chronic heart failure of the European Society of Cardiology (ESC)Developed with the special contribution of the Heart Failure Association (HFA) of the ESC. Eur. Heart J. 2016, 37, 2129-2200. [CrossRef] [PubMed]

60. Levy, J.B.; Jones, H.W.; Gordon, A.C. Selenium deficiency, reversible cardiomyopathy and short-term intravenous feeding. Postgrad. Med. J. 1994, 70, 235-236. [CrossRef] [PubMed]

61. Fleming, C.R.; Lie, J.T.; McCall, J.T.; O’Brien, J.F.; Baillie, E.E.; Thistle, J.L. Selenium deficiency and fatal cardiomyopathy in a patient on home parenteral nutrition. Gastroenterology 1982, 83, 689-693.

62. Burke, M.P.; Opeskin, K. Fulminant heart failure due to selenium deficiency cardiomyopathy (Keshan disease). Med. Sci. Law 2002, 42, 10-13. [CrossRef]

63. Oropeza-Moe, M.; Wisloff, H.; Bernhoft, A. Selenium deficiency associated porcine and human cardiomyopathies. J. Trace Elem. Med. Biol. 2015, 31, 148-156. [CrossRef]

64. Dabar, G.; Harmouche, C.; Habr, B.; Riachi, M.; Jaber, B. Shoshin Beriberi in Critically-Ill patients: Case series. Nutr. J. 2015, 14, 51. [CrossRef]

65. Ben-Hamouda, N.; Haesler, L.; Liaudet, L. Hyperlactatemia and lactic acidosis in the critically ill patient. Rev. Med. Suisse 2013, 9, 2335-2340. [PubMed] 
66. Smithline, H.A. Thiamine for the treatment of acute decompensated heart failure. Am. J. Emerg. Med. 2007, 25, 124-126. [CrossRef] [PubMed]

67. Rai, V.; Agrawal, D.K. Role of Vitamin D in Cardiovascular Diseases. Endocrinol. Metab. Clin. N. Am. 2017, 46, 1039-1059. [CrossRef] [PubMed]

68. Kalantari, H.; Barekat, S.M.; Maracy, M.R.; Azadbakht, L.; Shahshahan, Z. Nutritional status in patients with ulcerative colitis in Isfahan, Iran. Adv. Biomed. Res. 2014, 3, 58. [CrossRef] [PubMed]

69. O'Sullivan, M. Symposium on The challenge of translating nutrition research into public health nutrition. Session 3: Joint Nutrition Society and Irish Nutrition and Dietetic Institute Symposium on 'Nutrition and autoimmune disease'. Nutrition in Crohn's disease. Proc. Nutr. Soc. 2009, 68, 127-134. [CrossRef] [PubMed]

70. Hashemi, J.; Asadi, J.; Amiriani, T.; Besharat, S.; Roshandel, G.R.; Joshaghani, H.R. Serum vitamins A and E deficiencies in patients with inflammatory bowel disease. Saudi Med. J. 2013, 34, 432-434. [PubMed]

71. Torki, M.; Gholamrezaei, A.; Mirbagher, L.; Danesh, M.; Kheiri, S.; Emami, M.H. Vitamin D Deficiency Associated with Disease Activity in Patients with Inflammatory Bowel Diseases. Dig. Dis. Sci. 2015, 60, 3085-3091. [CrossRef] [PubMed]

72. Nowak, J.K.; Grzybowska-Chlebowczyk, U.; Landowski, P.; Szaflarska-Poplawska, A.; Klincewicz, B.; Adamczak, D.; Banasiewicz, T.; Plawski, A.; Walkowiak, J. Prevalence and correlates of vitamin K deficiency in children with inflammatory bowel disease. Sci. Rep. 2014, 4, 4768. [CrossRef]

73. Bermejo, F.; Algaba, A.; Guerra, I.; Chaparro, M.; De-La-Poza, G.; Valer, P.; Piqueras, B.; Bermejo, A.; Garcia-Alonso, J.; Perez, M.J.; et al. Should we monitor vitamin B12 and folate levels in Crohn's disease patients? Scand. J. Gastroenterol. 2013, 48, 1272-1277. [CrossRef]

74. Larnaout, A.; El-Euch, G.; Kchir, N.; Filali, A.; Hamida, M.B.; Hentati, F. Wernicke's encephalopathy in a patient with Crohn's disease: A pathological study. J. Neurol. 2001, 248, 57-60. [CrossRef]

75. Hiller, F.; Oldorff, L.; Besselt, K.; Kipp, A.P. Differential acute effects of selenomethionine and sodium selenite on the severity of colitis. Nutrients 2015, 7, 2687-2706. [CrossRef] [PubMed]

76. Saod, W.M.; Darwish, N.T.; Zaidan, T.A.; Alfalujie, A.W.A. Trace Elements in Sera of Patients with Hepatitis B: Determination and Analysis. In Proceedings of the Advanced nanotechnology in engineering and medical sciences (ANEMS) - International conference 2017, Langkawi, Malaysia, 20-21 November 2017.

77. Vagianos, K.; Bector, S.; McConnell, J.; Bernstein, C.N. Nutrition assessment of patients with inflammatory bowel disease. JPEN J. Parenter. Enter. Nutr. 2007, 31, 311-319. [CrossRef] [PubMed]

78. Himoto, T.; Masaki, T. Associations between Zinc Deficiency and Metabolic Abnormalities in Patients with Chronic Liver Disease. Nutrients 2018, 10, 88. [CrossRef] [PubMed]

79. Agarwal, A.; Avarebeel, S.; Choudhary, N.S.; Goudar, M.; Tejaswini, C.J. Correlation of Trace Elements in Patients of Chronic Liver Disease with Respect to Child- Turcotte- Pugh Scoring System. J. Clin. Diagn. Res. 2017, 11, OC25-OC28. [CrossRef] [PubMed]

80. Murakami, Y.; Koyabu, T.; Kawashima, A.; Kakibuchi, N.; Kawakami, T.; Takaguchi, K.; Kita, K.; Okita, M. Zinc supplementation prevents the increase of transaminase in chronic hepatitis $\mathrm{C}$ patients during combination therapy with pegylated interferon alpha-2b and ribavirin. J. Nutr. Sci. Vitaminol. (Tokyo) 2007, 53, 213-218. [CrossRef] [PubMed]

81. Schenker, S.; Halff, G.A. Nutritional therapy in alcoholic liver disease. Semin. Liver Dis. 1993, 13, $196-209$. [CrossRef] [PubMed]

82. Ermens, A.A.; Vlasveld, L.T.; Lindemans, J. Significance of elevated cobalamin (vitamin B12) levels in blood. Clin. Biochem. 2003, 36, 585-590. [CrossRef] [PubMed]

83. Lindor, K.D. Management of osteopenia of liver disease with special emphasis on primary biliary cirrhosis. Semin. Liver Dis. 1993, 13,367-373. [CrossRef]

84. Konstantakis, C.; Tselekouni, P.; Kalafateli, M.; Triantos, C. Vitamin D deficiency in patients with liver cirrhosis. Ann. Gastroenterol. 2016, 29, 297-306. [CrossRef]

85. Kitson, M.T.; Roberts, S.K. D-livering the message: The importance of vitamin D status in chronic liver disease. J. Hepatol. 2012, 57, 897-909. [CrossRef]

86. Patel, J.J.; Mundi, M.S.; Hurt, R.T.; Wolfe, B.; Martindale, R.G. Micronutrient Deficiencies After Bariatric Surgery: An Emphasis on Vitamins and Trace Minerals [Formula: See text]. Nutr. Clin. Pract. 2017, 32, 471-480. [CrossRef] [PubMed]

87. Roust, L.R.; DiBaise, J.K. Nutrient deficiencies prior to bariatric surgery. Curr. Opin. Clin. Nutr. Metab. Care 2017, 20, 138-144. [CrossRef] [PubMed] 
88. Singh, S.; Kumar, A. Wernicke encephalopathy after obesity surgery: A systematic review. Neurology 2007, 68, 807-811. [CrossRef] [PubMed]

89. Koffman, B.M.; Greenfield, L.J.; Ali, I.I.; Pirzada, N.A. Neurologic complications after surgery for obesity. Muscle Nerve 2006, 33, 166-176. [CrossRef] [PubMed]

90. Parrott, J.; Frank, L.; Rabena, R.; Craggs-Dino, L.; Isom, K.; Greiman, L. American Society for Metabolic and Bariatric Surgery Integrated Health Nutritional Guidelines for the Surgical Weight Loss Patient 2016 Update: Micronutrient. Surg. Obes. Relat. Dis. 2017, 13, 727-741. [CrossRef] [PubMed]

91. Jankowska, M.; Rutkowski, B.; Debska-Slizien, A. Vitamins and Microelement Bioavailability in Different Stages of Chronic Kidney Disease. Nutrients 2017, 9, 282. [CrossRef] [PubMed]

92. Jensen, G.; Goransson, L.; Fernstrom, A.; Furuland, H.; Christensen, J. Treatment of iron deficiency in patients with chronic kidney disease: A prospective observational study of iron isomaltoside (NIMO Scandinavia). Clin. Nephrol. 2019, 91, 246-253. [CrossRef]

93. Valenti, L.; Messa, P.; Pelusi, S.; Campostrini, N.; Girelli, D. Hepcidin levels in chronic hemodialysis patients: A critical evaluation. Clin. Chem. Lab. Med. 2014, 52, 613-619. [CrossRef]

94. Santos-Silva, A.; Ribeiro, S.; Reis, F.; Belo, L. Hepcidin in chronic kidney disease anemia. Vitam. Horm. 2019, 110, 243-264. [CrossRef]

95. Cozzolino, M.; Mangano, M.; Galassi, A.; Ciceri, P.; Messa, P.; Nigwekar, S. Vitamin K in Chronic Kidney Disease. Nutrients 2019, 11, 168. [CrossRef]

96. Hou, Y.C.; Lu, C.L.; Zheng, C.M.; Chen, R.M.; Lin, Y.F.; Liu, W.C.; Yen, T.H.; Chen, R.; Lu, K.C. Emerging Role of Vitamins D and K in Modulating Uremic Vascular Calcification: The aspect of passive calcification. Nutrients 2019, 11, 152. [CrossRef] [PubMed]

97. Richard, M.; Ducros, V.; Foret, M.; Arnaud, J.; Coudray, C.; Fusselier, M.; Favier, A. Reversal of selenium and zinc deficiencies in chronic hemodialysis patients by intravenous sodium selenite and zinc gluconate supplementation-Time-course of glutathione peroxidase repletion and lipid peroxidation decrease. Biol. Trace Elem. Res. 1993, 39, 149-159. [CrossRef] [PubMed]

98. Tonelli, M.; Wiebe, N.; Bello, A.; Field, C.J.; Gill, J.S.; Hemmelgarn, B.R.; Holmes, D.T.; Jindal, K.; Klarenbach, S.W.; Manns, B.J.; et al. Concentrations of Trace Elements and Clinical Outcomes in Hemodialysis Patients: A prospective cohort study. Clin. J. Am. Soc. Nephrol. 2018, 13, 907-915. [CrossRef] [PubMed]

99. Berger, M.M.; Shenkin, A.; Bollmann, M.D.; Revelly, J.P.; Cayeux, M.C.; Schaller, M.D.; Tappy, L.; Chioléro, R. Trace element balances during continuous venovenous hemodiafiltration (CVVHD). Kardiovasc. Med. 2003, 6 (Suppl. 5), 81S.

100. Schindler, K.; Themessl-Huber, M.; Hiesmayr, M.J.; Kosak, S.; Lainscak, M.; Laviano, A.; Ljungqvist, O.; Mouhieddine, M.; Schneider, S.; de van der Schueren, M.; et al. To eat or not to eat? Indicators for reduced food intake in 91,245 patients hospitalized on nutritionDays 2006-2014 in 56 countries worldwide: A descriptive analysis. Am. J. Clin. Nutr. 2016, 104, 1393-1402. [CrossRef] [PubMed]

101. Alberda, C.; Gramlich, L.; Jones, N.; Jeejeebhoy, K.; Day, A.G.; Dhaliwal, R.; Heyland, D.K. The relationship between nutritional intake and clinical outcomes in critically ill patients: Results of an international multicenter observational study. Intensive Care Med. 2009, 35, 1728-1737. [CrossRef] [PubMed]

102. Singer, P.; Reintam-Blaser, A.; Berger, M.M.; Alhazzani, W.; Calder, P.C.; Casaer, M.; Hiesmayr, M.J.; Mayer, K.; Montejo, J.M.; Pichard, C.; et al. ESPEN Guidelines: Nutrition in the ICU. Clin. Nutr. 2019, 38, 48-79. [CrossRef] [PubMed]

103. Pannerec, A.; Migliavacca, E.; De Castro, A.; Michaud, J.; Karaz, S.; Goulet, L.; Rezzi, S.; Ng, T.; Bosco, N.; Larbi, A.; et al. Vitamin B12 deficiency and impaired expression of amnionless during aging. J. Cachexia Sarcopenia Muscle 2018, 9, 41-52. [CrossRef]

104. Deutz, N.E.; Matheson, E.M.; Matarese, L.E.; Luo, M.; Baggs, G.E.; Nelson, J.L.; Hegazi, R.A.; Tappenden, K.A.; Ziegler, T.R.; Group, Nourish Study. Readmission and mortality in malnourished, older, hospitalized adults treated with a specialized oral nutritional supplement: A randomized clinical trial. Clin. Nutr. 2016, 35, 18-26. [CrossRef]

105. Friedli, N.; Stanga, Z.; Sobotka, L.; Culkin, A.; Kondrup, J.; Laviano, A.; Mueller, B.; Schuetz, P. Revisiting the refeeding syndrome: Results of a systematic review. Nutrition 2017, 35, 151-160. [CrossRef]

106. Sauer, A.; Goates, S.; Malone, A.; Mogensen, K.; Gewirtz, G.; Sulz, I.; Moick, S.; Laviano, A.; Hiesmayr, M. Prevalence of Malnutrition Risk and the Impact of Nutrition Risk on Hospital Outcomes: Results From nutritionDay in the U.S. JPEN. J. Parenter. Enter. Nutr. 2019. [CrossRef] [PubMed] 
107. Pruckner, N.; Baumgartner, J.; Hinterbuchinger, B.; Glahn, A.; Vyssoki, S.; Vyssoki, B. Thiamine Substitution in Alcohol Use Disorder: A Narrative Review of Medical Guidelines. Eur. Addict. Res. 2019, 25, 103-110. [CrossRef] [PubMed]

108. Curtis, L.; Bernier, P.; Jeejeebhoy, K.; Allard, J.; Duerksen, D.; Gramlich, L.; Laporte, M.; Keller, H. Costs of hospital malnutrition. Clin. Nutr. 2017, 36, 1391-1396. [CrossRef] [PubMed]

109. Hercberg, S.; Galan, P.; Preziosi, P.; Bertrais, S.; Mennen, L.; Malvy, D.; Roussel, A.; Favier, A.; Briancon, S. The SU.VI.MAX Study: A randomized, placebo-controlled trial of the health effects of antioxidant vitamins and minerals. Arch. Intern. Med. 2004, 164, 2335-2342. [CrossRef]

110. Visser, J.; Labadarios, D.; Blaauw, R. Micronutrient supplementation for critically ill adults: A systematic review and meta-analysis. Nutrition 2011, 27, 745-758. [CrossRef]

111. Wieser, S.; Brunner, B.; Tzogiou, C.; Plessow, R.; Zimmermann, M.B.; Farebrother, J.; Soofi, S.; Bhatti, Z.; Ahmed, I.; Bhutta, Z.A. Societal costs of micronutrient deficiencies in 6- to 59-month-old children in Pakistan. Food Nutr. Bull. 2017, 38, 485-500. [CrossRef]

112. Berger, M.M.; Reintam-Blaser, A.; Calder, P.C.; Casaer, M.; Hiesmayr, M.; Mayer, K.; Montejo, J.C.; Pichard, P.; Preiser, J.; van Zanten, A.; et al. Monitoring nutrition in the ICU. Clin. Nutr. 2019, 38, 584-593. [CrossRef]

113. Gagnon, G.; Voirol, P.; Soguel, L.; Boulat, O.; Berger, M.M. Trace element monitoring in the ICU: Quality and economic impact of a change in sampling practice. Clin. Nutr. 2014, 34, 422-427. [CrossRef]

(C) 2019 by the authors. Licensee MDPI, Basel, Switzerland. This article is an open access article distributed under the terms and conditions of the Creative Commons Attribution (CC BY) license (http://creativecommons.org/licenses/by/4.0/). 